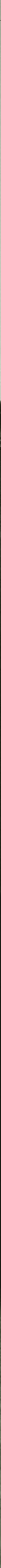




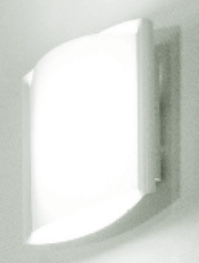

11

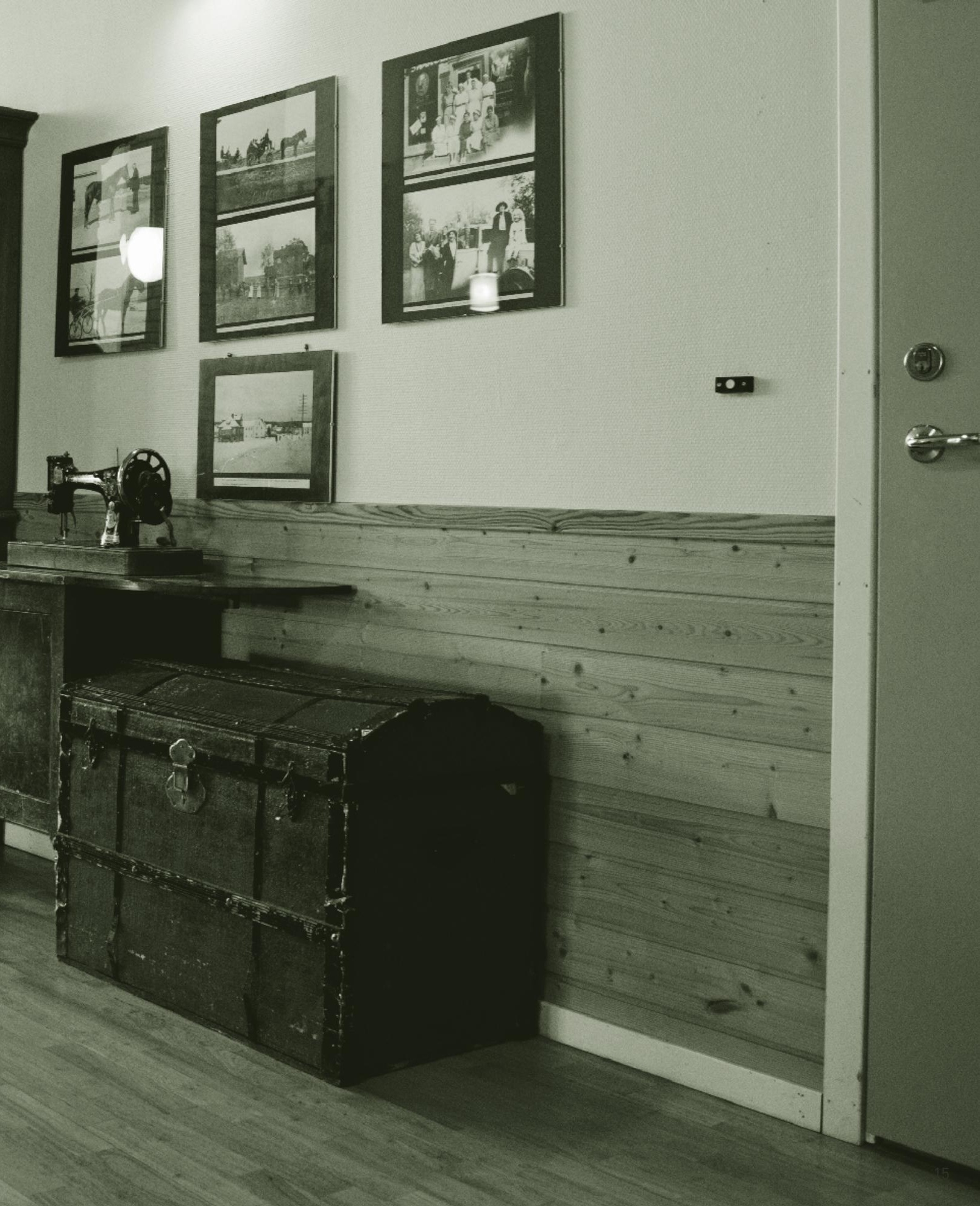



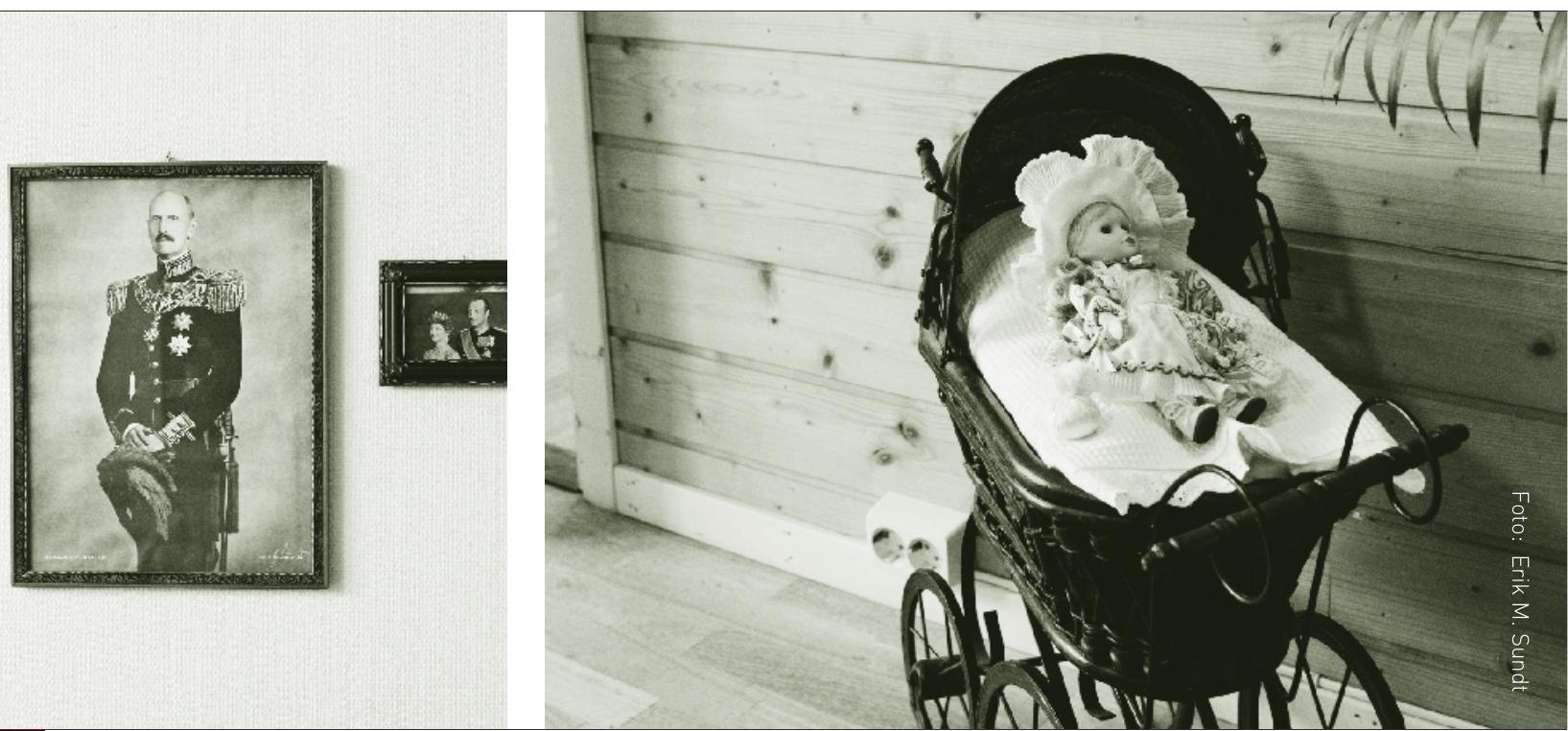

Bakgrunn: Miljøbehandling benyttes i økende grad i demensomsorgen. De fysiske omgivelsene er ett av elementene i metoden. Kunnskap om hvordan personalet kan bruke de fysiske omgivelsene i tilretteleggingen av god omsorg for personer med demens er viktig.

Hensikt: Undersøke hva vi vet om hvilke faktorer i de fysiske omgivelsene som har betydning for funksjon, trivsel og velvære hos personer med demens.

Metode: Systematiske søk i databasene Cinahl, Medline, PsychInfo, Cochrane og Embase ble gjennom- ført i januar/februar 2010 og oktober 2010.

Resultater: Femten oversiktsartikler ble inkludert, tolv hadde fokus på «atferdsproblematikk». Fire hovedkategorier oppsummeres: Faktorer som bidrar til (1) orientering, (2) trygghet og sikkerhet, (3) personliggjøring og hjemliggjøring og (4) stimuli. Hovedfokus i artiklene er ulike former for stimulireduksjon. Få studier vektlegger bruk av positive stimuli og faktorer som kan bidra til trivsel og velvære. Tre oversiktsartikler presenterer teoretiske perspektiver, som hovedsakelig brukes for å forklare utfordrende atferd.
Kvaliteten på oversiktsartiklene og primærstudiene varierer. Mange av primærstudiene er små og for flere av tiltakene er ikke resultatene konsistente. Det vitenskapelige grunnlaget vurderes derfor som lavt.

Konklusjon: Litteraturgjennomgangen viser at hovedfokus har vært på faktorer i de fysiske omgivelsene som bidrar til å redusere utfordrende atferd. Det vitenskapelige grunnlaget for tiltakene innenfor demensvennlig design er svakt. Studier som fokuserer på hvordan det fysiske miljøet kan brukes for å skape trivsel og velvære for personer med demens er nødvendig.
Which factors in the physical environment promote or hinder function, thriving and well-being among persons with dementia? A literature review

Background: Psychosocial treatment is increasingly utilized in care of persons with dementia. Factors in the physical environment are part of this method. Knowledge about how carers can make use of the physical environment to improve dementia care quality is important.

Objective: Explore the state of knowledge about factors in the physical environment that impact on functioning, thriving and well-being among persons with dementia.
Methods: Cinahl, Medline, PsychInfo, Cochrane and Embase databases were used for systematic literature searches in January/ February and October 2010.

Results: Fifteen review articles were included. Twelve focused on behavioural difficulties. Four main categories are summarized: factors contributing to (1) orientation, (2) safety and security, (3) personalization and homelikeness, and (4) stimulation. The main focus is stimuli reduction. Few studies emphasize use of positive stimuli and factors contributing to thriving and wellbeing. Three articles describe theoretical perspectives, used primarily to explain challenging behaviour.
The quality of the review articles and primary studies varies. Many of the studies are small and the results are inconsistent which makes the scientific evidence limited.

Conclusion: So far, the main focus has been on factors in the physical environment that reduce challenging behaviours. The scientific evidence for using physical factors in the environment to improve care is limited. Studies focusing on how the physical environment can be used to develop thriving and well-being among persons with dementia are needed.

Key words: dementia, health facility environment, interior design and furnishing, review 


\section{Hvilke faktorer i de fysiske om- givelsene hemmer og fremmer funksjon, trivsel og velvære hos personer med demens?}

Forfattere: Ådel Bergland

og Marit Kirkevold

\section{NøKKELORD}

- Demens

- Miljø

- Litteraturstudie

\section{INNLEDNING}

Miljøbehandling inngår som et viktig element i demensomsorgen og innebærer at fysiske, psykiske og sosiale faktorer i omgivelsene tilrettelegges på en slik måte at personer med demens kan fungere optimalt til tross for svikten sykdommen medfører. De fysiske omgivelsene påvirker det psykososiale miljøet fordi de tilrettelegger eller hindrer for aktiviteter, sosial interaksjon og psykologisk velvære hos personer med demens $(1,2)$. Målsettingen med miljøbehandling er å bedre funksjonsnivået i dagliglivet og bidra til økt livskvalitet, trivsel og velvære (3). Omgivelsene skal ikke kun være til glede, men ha en terapeutisk effekt og inngå som et ledd i omsorgen for personer med demens (4). Ut fra et sykepleiefaglig ståsted er kunnskap om hvordan personalet kan bruke de fysiske omgivelsene i tilretteleggingen av god omsorg for personer med demens viktig.

Hensikten med litteraturstudien er å undersøke hva vi vet om hvilke faktorer i de fysiske omgivelsene som har betydning for trivsel, velvære og funksjon hos personer med demens.

\section{METODE}

Litteraturstudien er basert på oversiktsartikler som oppsummerer empiriske studier av fysiske omgivelsers betydning for personer med demens. Hensikten med å sammenfatte oversiktsartikler - en «review av reviews»/«paraply-review»er å undersøke det vitenskapelige grunnlaget for flere faktorer og bidra til å gjøre kunnskapsgrunnlaget enkelt tilgjengelig, blant annet for det kliniske feltet (5).

Systematiske søk i databasene Cinahl, Medline, PsychInfo, Cochrane og Embase ble gjennomført i januar og februar 2010. Følgende nøkkelord ble brukt: «dementia eller Alzheimer's disease» som ble kombinert med «interior design, furnishings, nursing home design and construction, architecture, environment, health facility environment, samt «dementia friendly». Søkene ble avgrenset til review artikler, språk (engelsk, dansk, svensk og norsk) og tidsrommet 1990 til 2010. Det ble gjennomført et nytt søk i oktober 2010. Dette søket identifiserte en

Hva tilfører denne artikkelen? Artikkelen belyser hva som foreligger av forskningsbasert kunnskap om miljøfaktorer som gir funksjon og trivsel for personer med demens.

Mer om forfatterne: Ådel Bergland er sykepleier, dr. polit og førsteamanuensis ved Universitetet i Oslo, Institutt for sykepleievitenskap og helsefag, Gruppe for eldreomsorgsforskning og Diakonhjemmet Høgskole. Marit Kirkevold er sykepleier, EdD og professor ved Institutt for sykepleievitenskap og helsefag, Universitetet i Oslo. Kontakt: adel. berglandamedisin.uio.no. 
ny oversiktsartikkel, som ikke ble inkludert på grunn av lav kvalitet (6).

\section{Kvalitetsvurdering}

Kvalitetsvurderingen av oversiktsartiklene er basert på Kunnskapssenterets kriterier for vurdering av systematiske oversikter (tabell 1) (7). Vurderingen av artiklene ble gjort ved hjelp av kategoriene: Møtt, uklar/delvis møtt og ikke møtt (5).

Vurderingen av det vitenskapelige grunnlaget for hver av faktorene som bidro til demensvennlige fysiske omgivelser, ble gjort på bakgrunn av Jamtvedt og medarbeideres (5) kriterier (se tabell 2). Kriteriene baseres både på kvalitetsvurdering av

TABELL 1: Kriterier for kvalitetsvurdering av oversiktsartiklene

Spørsmål som ble stilt

i kvalitetsvurderingen av oversiktsartiklene

- Beskrives metodene som ble brukt for å finne primærstudiene?

- Ble det utført et tilfredsstillende litteratur$s ø k$ ?

- Beskrives inklusjonskriteriene for artiklene?

- Ble det sikret mot systematiske skjevheter ved utvelgelse av studiene?

- Ble kriteriene for å vurdere intern kvalitet beskrevet?

- Ble validiteten til studiene vurdert ved hjelp av relevante kriterier?

- Ble metodene som ble brukt for å sammenfatte resultatene klart beskrevet?

- Ble resultatene sammenfattet på en forsvarlig måte?

- Ble forfatternes konklusjoner underbygget med data og/eller analyse fra reviewene?

TABELL 2: Kriterier for vurdering av vitenskapelig kvalitet på de ulike faktorene

Vitenskapelig kvalitet

God

vitenskapelig kvalitet

Moderat

vitenskapelig kvalitet

Lav

vitenskapelig kvalitet

Manglende

vitenskapelig grunnlag ut

fra oversiktsartiklene
Kriterier for

vurdering av kvalitet

Høy kvalitet: minst 7 av kriteriene var møtt Moderat kvalitet: minst 4 av kriteriene var møtt Lav kvalitet: færre enn fire av kriteriene var møtt

(1)


tekst i UiO's elektroniske tidsskrifter, ble dette gjort for å ha et bredere vurderingsgrunnlag enn bare tittelen.

Totalt 57 artikler ble vurdert som relevante for videre vurdering $\mathrm{i}$ fulltekst. I den første gjennomgangen ble tre duplikater tatt ut. Artikler lest i fulltekstversjon som viste seg ikke å ha fokus på personer med demens eller fysiske omgivelser, ble ekskludert. Dette førte til 41 artikler vurdert som fulltekstartikler. Litteraturlistene til alle fulltekstartiklene ble gjennomgått, åtte nye oversiktsartikler ble identifisert. Day og Calkins kapittel i Handbook of Environmental Psychology (4) ble hyppig referert til og derfor inkludert. Etter en grundig vurdering av de 49 artiklene ble 19 inkludert og 30 ekskludert. Eksklusjonskriteriet var at artiklene ikke oppsummerte empiriske studier systematisk. Tolv av oversiktsartiklene hadde fokus på «atferdsproblematikk» hos personer med demens. Vi inkluderte artiklene når tiltak relatert til de fysiske omgivelsene ble oppsummert og det var mulig å trekke ut empiriske studier med fokus på de fysiske omgivelsene. Av de 19 oversiktsartiklene ble ti vurdert til å ha høy kvalitet, fem hadde moderat og fire hadde lav kvalitet. Landmark og medarbeideres oppsummering ble vurdert til å være av høy kvalitet, men baseres i stor grad på oppsummeringen hos Day og medarbeidere (9), som ble vurdert til å ha moderat kvalitet. Artiklene med lav kvalitet ble ekskludert (4, 10-12). Litteraturgjennomgangen er derfor basert på 15 oversiktsartikler. Åtte av ti oversiktsartikler med høy kvalitet hadde fokus på «atferdsproblematikk».

\section{TEORETISKE PERSPEKTIVER}

Tre av oversiktsartiklene presenterer til sammen fire teoretiske perspektiver (teorier og modeller). Hovedfokus i disse er funksjon og mestring, samt stress som kan føre til uønsket atferd, når omgivelsene ikke er tilpasset personens kognitive funksjonsnivå. De øvrige oversiktsartiklene presenterer ingen teoretiske perspektiver. små krav kan føre til apati (8).

Hall og Buckwalters (14) modell Progressively Lowered Stress Threshold (PLST) fokuserer på atferd som resultat av personens evne til å tilpasse seg og mestre omgivelsene. På grunn av sykdomsutviklingen reduseres stressterskelen hos personer med demens. De blir dårligere i stand til å motta og håndtere informasjon og stimuli fra

\section{Mer institusjonsorientert servering som
bruk av serveringsbrett, bidro til mer uro.}

Lawton og Nahemow's (13) modell "ecological model of aging» fokuserer på sammenhengen mellom atferd, personens kompetanse og krav fra omgivelsene. Samspillet er optimalt og personen fungerer optimalt når kravene fra omgivelsene er tilpasset personens kompetanse. For høye krav kan skape angst og «atferdsforstyrrelser». For omgivelsene. Når stressterskelen overskrides, får personen angst som resulterer i ulike former for utfordrende atferd.

Med utgangspunkt i Barris og medarbeideres omgivelsesmodell har Corcoran og Gitlin (15) videreutviklet denne til demensomsorgen. Modellen beskriver fire hierarkiske lag som påvirker hverandre gjensi-

TABELL 3: Oversikt over analysekategoriene

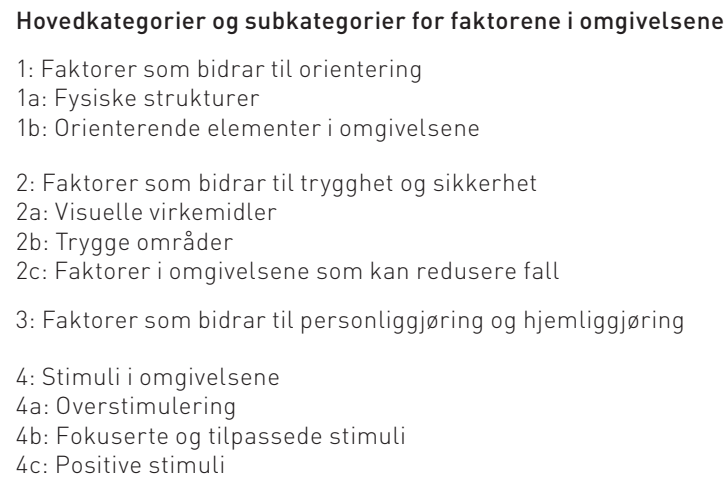

\section{Kategorier for utfallsmålene}

Fysisk og mental funksjon

Adferd

Sosial funksjon

Subjektive opplevelser (Trivsel og velvære)

Annet 
dig: Objekter i de fysiske omgivelsene, dagliglivets oppgaver, sosiale grupper og verdiene i pleiekulturen. Lagene kan tilpasses for å skape en balanse mellom omgivelsene og personens mentale og fysiske kompetanse (16).

Cohen-Mansfield (17) forklarer utfordrende atferd hos personer med demens som et resultat av at behov ikke er møtt (Unmet needs model). Atferden kan skyldes mangel på stimuli entydig. Dette gjør det vanskelig å sammenligne studier og komme med anbefalinger. I studier hvor ulike fysiske utforminger vurderes i forhold til hverandre er utvalgene små, ofte bare en avdeling/enhet i hver kategori. Utfallsmålene fokuserer i hovedsak på beboernes funksjon: Orientering, funksjon i avdelingen, grad av sosial interaksjon og aktivitet $(8,9)$.

Enkel utforming fremmer mulighetene for å orientere seg

\section{Når beboerne ble synlige for personalet fra vaktrommet, ble omfanget av direkte sam- handling mellon pleiere og beboere redusert.}

(understimulering), kjedsomhet og ensomhet. Omgivelser som bidrar med positive stimuli, aktivitet og sosialt samvær kan derfor redusere slik atferd.

\section{Utfallsmål}

Tolv av oversiktsartiklene har fokus på «atferdsproblematikk». Dette innebærer at utfallsmålene fokuserer på atferd og/eller nevropsykiatriske symptomer. Hovedfokus er atferdsregulering og funksjon. Enkeltstudier har fokus på å bruke positive stimuli i miljøet, men også her er funksjon og atferdsregulering ofte målet.

\section{Faktorer som bidrar til orientering}

Informasjon fra omgivelsene kan bidra til orientering. Seks oversiktsartikler gjennomgår den fysiske utformingen av bygningen/avdelingen og tiltak personalet kan iverksette for å gjøre det enklere å orientere seg $\mathrm{i}$ avdelingen $(8,9,16,18-20)$.

\section{Fysiske strukturer}

Begrepsbruken for den fysiske utformingen av avdelinger er lite og finne frem når det kombineres med informasjon fra omgivelsene. Gruppering av rom i mindre enheter med tilknyttede fellesrom gjør det enklere å orientere seg sammenlignet med store fellesrom plassert lenger fra beboerrommene. Avdelinger hvor beboere kommer direkte inn i fellesrom når de kommer ut av eget rom, er vist å gi bedre orienteringsevne, økt sosial interaksjon, økt fysisk aktivitet og større muligheter for å variere hvor beboerne tilbringer tiden. Lange korridorer bidrar til rastløshet og apraksi. I den hensikt å lage kortere korridorer og færre dører for beboere å forholde seg til, er ulike fysiske utforminger forsøkt. Avdelinger hvor korridoren er formet som L, H eller firkant er vist å gi bedre romorientering. Når beboerne ble synlige for personalet fra vaktrommet, ble omfanget av direkte samhandling mellom pleiere og beboere redusert $(8,9)$.

\section{Orienterende elementer}

I studier av ulike orienterende elementer er utfallsmålene orientering og atferd. Bruk av skilting viser ikke konsistente resultater. To studier har vist at nummer på beboerrommene, bruk av fargekoder, skilt med bokstav og bildesymboler og andre orienterende elementer (klokke, tavle) bedret orienteringsevnen. Andre studier har vist at kun når skilting kombineres med realitetsorientering eller ting som dro oppmerksomheten mot skiltet, hadde det betydning for pasientenes evne til å orientere seg $i$ avdelingen og ga mindre uro. Den formen for merking som bidro til at flest fant toalettet, var skilt med ordet toalett og piler på gulvet som viste vei til toalettet. Dette gjaldt beboere som hadde liten eller moderat kognitiv svikt/ demensutvikling $(8,9,16,18)$.

Det er lite dokumentasjon for betydningen av personlige gjenstander i monter ved døren til rommet som orienterende elementer. En studie viste at personlige gjenstander bidro til noe $ø \mathrm{kt}$ gjenkjenning av rom hos beboere med moderat demens. Beboere med høyere funksjonsevne orienterte seg uten slike gjenstander, mens de ikke var til hjelp hos personer med alvorlig demens $(8,9)$.

\section{Faktorer som bidrar til trygghet og sikkerhet}

Trygghet og sikkerhet kan oppnås både ved tiltak som hindrer beboere i å gå ut og tiltak som gir beboere bevegelsesfrihet i trygge tilrettelagte omgivelser. Ni oversiktsartikler oppsummerer slike faktorer $(8,9,16-22)$.

\section{Visuelle virkemidler}

I studier som involverer visuelle virkemidler er utfallsmålene atferd og atferdsregulering. Subjektive barrierer brukes for å hindre at beboere forlater avdelingen eller hindre at de går inn på rom/ områder i sykehjemmet hvor de ikke skal være. De inkluderte 
studiene er små (åtte til 30 pasienter) og resultatene er ikke entydige. En studie viste at striper på gulvet foran inngangsdøren ikke hadde effekt på forsøkene på å komme ut, to andre studier at det bidro til færre forsøk. I en studie førte plassering av et stort speil foran døren til reduksjon i antall forsøk på å komme ut $(8$, $9,17,18)$.

\section{Trygge områder}

Tilrettelegging av trygge uteområder er et alternativ til å hindre beboere i å gå ut. Utfallsmålene i disse studiene er atferdsregulering og subjektive opplevelser. Den atferdsregulerende effekten var uklar. En studie viste at tilgang til utearealer ikke bidro til reduksjon av utfordrende atferd, en annen reduksjon av mindre alvorlige "atferdsproblemer», men ikke av alvorlige. Tilgang til utearealer førte til at beboere tilbrakte tid ute og behovet for medikamenter ble redusert. Mens beboerne oppholdt seg i hagen hadde de positive opplevelser som samtale, spill og lesing. Personalet og pårørende mente at opphold i hagen ga bedre livskvalitet og humør $(8,9,17,19,20)$.

\section{Reduksjon av fall}

En studie viste at faktorer i de fysiske omgivelsene utløste en liten andel (7,9 prosent) av fallene $\mathrm{i}$ institusjonen. Lave møbler, madrasser på gulvet og tiltak på baderommet medførte reduksjon i fall - også etter sju måneder (8).

\section{Personliggjøring \\ og hjemliggjøring}

Flere faktorer bidrar til personliggjøring og hjemliggjøring. Tre oversiktsartikler $(8,9,16)$ oppsummerer slike faktorer. Utfallsmålene er atferd, funksjon, sykdomsutvikling og velvære.

Omgivelser med personlig og hjemlig preg beskrives oftest som positive og institusjonspreg som negative faktorer for personer med demens, men enkelte studier "utfordrer» disse resultatene. Sammenlignet med personer med demens i tradisjonelle sykehjemsavdelinger, beholdt beboere $\mathrm{i}$ avdelinger med lite institusjonspreg sine motoriske funksjoner bedre, de var mindre aggressive, det var færre forsøk på å forlate avdelingen eller gå inn på andres rom. Beboerne brukte mindre beroligende midler og hadde mindre angst. Hjemlige omgivelser er også vist å gi økt sosial kontakt. Stor grad av hjemlighet er rapportert å kunne gi mer uro, eksempelvis selvhevdelse, økt forvirring og dårligere ernæring $(8,9)$.

Å innta måltidene $\mathrm{i}$ «hjem- og familielignende» omgivelser inne på avdelingen hvor maten serveres ved små bord, er rapportert å føre til økt inntak av mat, bedre sosial kontakt og kommunikasjon. Mer institusjonsorientert servering som bruk av serveringsbrett, bidro til mer uro $(8,9,16)$.

Private rom gir beboere muligheter for å skape personlige omgivelser og større valgfrihet om hvor de vil være. En studie viste at etter ombygging til enerom tilbrakte beboerne mindre tid på rommet, de var mer i bevegelse, men hadde likevel mindre samvær med andre beboere. Personlig preg og private møbler på rommet er vist å bidra til økt velvære og trivsel og at beboere viste følelser bedre $(8,9)$. Pleiepersonalet foretrekker avdelinger som ikke er institusjonspregede (9). Et hjemlig miljø har ikke vist å ha betydning for progresjon $\mathrm{i}$ den kognitive svikten, funksjonsfall eller mortalitet (8).

\section{Stimuli i omgivelsene}

Stimuli påvirker personer med demens på ulike måter og oppsummeres i 13 oversiktsartikler (8, 9, 16-20, 22-27). Overstimulering som årsak til stress og uønsket atferd er hovedfokus. Færre studier viser konsekvenser av understimulering og hvordan stimuli kan brukes målrettet for å fremme funksjon, trivsel og velvære.

\section{Overstimulering}

Overstimulering kan skyldes for mange og/eller uforståelig stimuli. Stimulireduksjon kan skje gjennom fysiske strukturer og/ eller tilpasning av interiør, rutiner og aktiviteter. Et hovedfokus i oversiktsartiklene er tiltak for å redusere overstimulering. Utfallsmålene i de oppsummerte studiene er atferd, funksjon og livskvalitet.

Store enheter rapporteres å resultere i overstimulering, mens små oversiktlige enheter gir stimulireduksjon $(8,9)$. Store boenheter bidrar til negative konsekvenser med hensyn til atferd, større grad av intellektuell forverring, emosjonelle problemer og økt forbruk av medisiner og tvang $(8,9,24)$.

Betydningen av stimulireduksjon gjennom små tilrettelagte enheter er ikke entydig. Flytting til små enheter er vist å føre til at den kognitive funksjonen opprettholdes lenger, bedret funksjonsnivå og større grad av mobilitet. Andre studier har vist at små enheter ikke har betydning for progresjonen av den kognitive svikten. Flyttingen kan ha betydning på kort sikt, men ikke etter tre år. En studie fant redusert forekomst av katastrofereaksjoner hos personer i skjermede enheter, en annen at beboerne var mer fysisk aggressive, men de hadde også alvorligere kognitiv svikt sammenlignet med beboere i vanlige sykehjemsavdelinger $(8$, 
9, 24). En cochrane-oversikt viste at skjermede enheter ikke reduserte «atferdsproblemer» (23). Robinson og medarbeidere (25) konkluderte med at skjermede enheter ikke reduserte vandring.

Små tilrettelagte enheter bidro positivt til livskvalitetsmål som emosjonell helse, mindre angst og depresjon. Det var mer kontakt beboere imellom, forbedring av eller forsinket reduksjon i kommunikasjonsferdigheter, mindre bruk av tvang og lavere forbruk av beroligende midler og antibiotika. Små enheter ga bedre muligheter for etablering av relasjoner med personale, samt at beboerne fikk mer tilsyn og veiledning. Personale fikk bedre oversikt og ble bedre kjent med beboerne. Små enheter kan imidlertid føre til mindre deltakelse i organiserte aktiviteter. Pårørende og personale er mer tilfredse med små enheter og pårørende opplever mindre belastninger $(8,9,18,20,28)$.

Overstimulering kan også skyldes stimuli i avdelingen som farger, mennesker, lyder, forstyrrende atferd fra andre og/eller skremmende opplevelser på film eller TV. Korridorer og heiser fremheves som støyende områder. Bading er en situasjon som innebærer høyt stressnivå på grunn av overstimulering og/eller uforståelige stimuli og beskrives som en av de mest belastende oppgavene i omsorgen for personer med demens $(8$, $9,17,22)$.

Nøytrale omgivelser med hensyn til farger og design, faste rutiner og reduksjon av støy bidro til reduksjon av "atferdsforstyrrelser", færre katastrofereaksjoner, mindre bruk av medikamenter, mindre bruk av tvang, positive interaksjoner og vektøkning. Rolige miljøer bidro også til bedre orientering $(8,9)$.

\section{Fokusert og} tilpasset stimuli

Stimuli kan også brukes for å fremheve gjenstander som personer med demens skal konsentrere seg om. Utfallsmålene i disse studiene er funksjon.

En liten studie viste at beboere spiste mer og var mindre urolige når det var godt lys og kontraster ved bruk av duk. Synlig og lett tilgjengelig snacks i kjøleskap med vindu førte i liten grad til at beboere forsynte seg på eget initiativ. Når toalettet var synlig fra fellesrommet hvor beboerne oppholdt seg, økte bruken av toalettet, særlig hos beboere som var kommet langt i demensutviklingen. En liten studie viste at når klesskapet var organisert slik at klærne hang i den rekkefølgen de skulle tas på, ble beboerne mer selvhjulpne. Skjerming fra andre stimuli bidro til økt konsentrasjon på oppgaven som skulle gjøres. I enheter med dårlig belysning var det vanskeligere for personer med demens å orientere seg $(8,9,16)$.

\section{Positive stimuli}

Ulike positive stimuli kan berike det fysiske miljøet for personer med demens og motvirke understimulering. Utfallsmålene fokuserer på atferd og funksjon.

I en studie gjorde pleiepersonalet bruk av naturelementer som fuglesang og bilder av natur. Dette bidro til mindre uro, verbal og fysisk utagering i forbindelse med bading. En annen studie viste at personer med demens som vandret, oppholdt seg mer i den delen av korridoren som var «beriket» med positive stimuli. Bruk av naturlyder reduserte verbal uro. Tilførsel av positive stimuli som lyd, lys og lukt i kombinasjon ga positive utslag på sosial interaksjon og egenomsorg, men ikke kognitiv funksjon $(8,9,16,17$, 19, 22).

Lys har vært brukt for å regulere døgnrytme og atferd hos personer med demens. Noen studier har vist at lys normaliserte døgnrytmen og reduserte «atferdsproblemer», andre ikke $(8,9,17,20$, $26,27)$. En oversikt over resultatene i hver oversiktsartikkel finnes i tabell 4 på sykepleien.no.

\section{DISKUSJON}

Faktorene som oppsummeres omhandler både den fysiske utformingen av bygninger og avdelinger, som pleiepersonalet har liten innvirkning på, og faktorer personalet kan bruke for å tilrettelegge for beboernes funksjon og trivsel. Gjennomgangen av oversiktsartiklene indikerer at det vitenskapelige grunnlaget for tiltakene innenfor demensvennlig design er svakt (tabell 5). En stor andel av studiene er små og ofte inkluderes bare en setting (11). Flere av studiene er casestudier med kartlegging før og etter ombygging og renovering av institusjonen. Noen aspekter ved det fysiske miljøet for personer med demens kan være viktig selv om det ikke foreligger god vitenskapelig dokumentasjon, eksempelvis enerom og pene ikke-institusjonspregede omgivelser.

Feltet har flere metodiske svakheter. Det preges av definisjonsmessige uklarheter og begrepsavklaringer er nødvendig. I en litteraturgjennomgang fant Verbeek og medarbeidere (29) 11 ulike betegnelser på botilbud for personer med demens, eksempelvis skjermede enheter, gruppeboliger og "Green houses». Det er heller ingen klar angivelse av antall beboere i små og store enheter (9). Det kan bety at ulike botilbud oppsummeres og sammenlignes. Begrepene «ikke- 
institusjonspreg» og «hjemlig» er ikke entydige. Hjemlig kan bety å benytte møbler av tre og stoppede møbler, ikke møbler av plast og/eller metall som gir enkel rengjøring. Det kan også bety at møblene ligner det de eldre selv ville ha eller hadde i sitt hjem, noe som varierer. I andre studier innebærer institusjonspreg at omgivelsene er monotone, mens hjemlig preg innebærer bruk av farger og mønstre. Hjemlig preg kan også bety at beboerne har sine private møbler på rommet $(10,11)$.

Beboere i botilbud som sammenlignes, er ofte ulike med hensyn til sykdomsutvikling, funksjonsnivå og grad av utfordrende atferd. Det foreligger ikke RCT-studier og det argumenteres for at det oppfattes som uetisk å gjennomføre slike (23).

I mange av studiene iverksettes flere intervensjoner samtidig og det er vanskelig å vurdere

TABELL 5: Oversikt over ulike faktorer og vurdering av det vitenskapelige grunnlaget for hver av faktorene

\begin{tabular}{|c|c|c|}
\hline $\begin{array}{l}\text { Faktorer i det } \\
\text { fysiske miljøet }\end{array}$ & $\begin{array}{l}\text { Antall studier og } \\
\text { inkluderte deltakere }\end{array}$ & Vitenskapelig kvalitet basert på kriteriene i tabell 2 \\
\hline \multirow[t]{2}{*}{$\begin{array}{l}\text { 1: Faktorer som } \\
\text { bidrar til orien- } \\
\text { tering }\end{array}$} & $\begin{array}{l}\text { Fysiske strukturer } \\
5 \text { studier } \\
N=322 \text { beboere } \\
N=140 \text { personalet } \\
N=220 \text { pårørende }\end{array}$ & $\begin{array}{l}\text { Lav vitenskapelig kvalitet basert på oversiktsartikler av } \\
\text { ulik kvalitet og inkonsistente resultater i oversiktsartiklene } \\
\text { og i primærstudiene. }\end{array}$ \\
\hline & $\begin{array}{l}\text { Orienterende elementer } \\
\text { i omgivelsene } \\
8 \text { studier } \\
N=167 \text { beboere } \\
N=220 \text { pårørende } \\
N=140 \text { personale }\end{array}$ & $\begin{array}{l}\text { Lav vitenskapelig kvalitet basert på oversiktsartikler av } \\
\text { varierende kvalitet og inkonsistente resultater i oversikts- } \\
\text { artiklene. Primærstudiene er små med moderat til lav } \\
\text { kvalitet. (N fra } 8 \text { til 56) }\end{array}$ \\
\hline \multirow[t]{3}{*}{$\begin{array}{l}\text { 2: Faktorer som } \\
\text { bidrar til trygghet } \\
\text { og sikkerhet }\end{array}$} & $\begin{array}{l}\text { Visuelle virkemidler } \\
11 \text { studier } \\
\mathrm{N}=104 \text { beboere } \\
\text { Trygge områder } \\
7 \text { studier }\end{array}$ & $\begin{array}{l}\text { Lav vitenskapelig kvalitet basert på oversiktsartikler av } \\
\text { ulik kvalitet, ikke konsistente resultater med hensyn til } \\
\text { bruk av subjektive barrierer. Primærstudiene er små. (N } \\
\text { fra } 3 \text { til 30) }\end{array}$ \\
\hline & $\begin{array}{l}\mathrm{N}=266 \text { beboere } \\
\text { Faktorer i omgivelsene } \\
\text { som kan redusere fall } \\
2 \text { studier } \\
\mathrm{N}=12 \text { eldre personer }\end{array}$ & $\begin{array}{l}\text { Lav vitenskapelig kvalitet basert på oversiktsartikler av } \\
\text { ulik kvalitet og ikke konsistente resultater med hensyn } \\
\text { til betydningen for adferd/adferdsproblemer. Få og små } \\
\text { studier om bruk av tryggeområder. (N fra } 7 \text { til 130) }\end{array}$ \\
\hline & $\mathrm{N}=1$ avdeling & Lav vitenskapelig kvalitet ut fra få og små primærstudier. \\
\hline $\begin{array}{l}\text { 3: Faktorer som } \\
\text { bidrar til per- } \\
\text { sonliggjøring og } \\
\text { hjemliggjøring }\end{array}$ & $\begin{array}{l}16 \text { studier } \\
N=78214 \\
N=43 \text { personale } \\
1 \text { studie oppgir enkeltregistreringer: } \\
3723 \text { i } 53 \text { skjermede enheter }\end{array}$ & $\begin{array}{l}\text { Lav vitenskapelig kvalitet basert på oversiktsartikler av } \\
\text { ulik kvalitet, inkonsistente resultater med hensyn til hjem- } \\
\text { liggjøring og små studier om betydningen av personlig- } \\
\text { gjøring av spiserom og beboerrom. }\end{array}$ \\
\hline \multirow[t]{3}{*}{$\begin{array}{l}\text { 4: Stimuli } \\
\text { i omgivelsene }\end{array}$} & $\begin{array}{l}\text { Overstimulering } \\
46 \text { studier } \\
N=5485 \text { beboere } \\
N=53 \text { personale } \\
2 \text { studier oppgir enheter: } N=82 \\
1 \text { studie oppgir } 3723 \text { enkeltregistreringer } \\
\text { i } 53 \text { SCU }\end{array}$ & $\begin{array}{l}\text { Lav vitenskapelig kvalitet basert på oversiktsartikler av } \\
\text { ulik kvalitet og inkonsistente resultater i oversiktsarti- } \\
\text { klene og primærstudierne om betydningen av skjermede } \\
\text { enheter. }\end{array}$ \\
\hline & $\begin{array}{l}\text { Fokuserte og tilpassede stimuli } \\
9 \text { studier } \\
\mathrm{N}=217 \text { beboere } \\
1 \text { studie hvor } \mathrm{N} \text { ikke oppgis }\end{array}$ & $\begin{array}{l}\text { Lav vitenskapelig kvalitet basert på oversiktsartikler av } \\
\text { ulike kvalitet. Primærstudiene om tilpasning og fokusering } \\
\text { av stimuli er få og små. ( } N \text { varierer fra } 8 \text { til 79) }\end{array}$ \\
\hline & $\begin{array}{l}\text { Positive stimuli } \\
16 \text { studier } \\
N=342 \text { beboere } \\
N=23 \text { pårørende } \\
N=29 \text { personale }\end{array}$ & $\begin{array}{l}\text { Lav vitenskapelig kvalitet basert på oversiktsartikler av } \\
\text { ulike kvalitet. Primærstudiene om bruk av positive stimuli } \\
\text { er få og små ( } N \text { varierer fra } 5 \text { til 66). }\end{array}$ \\
\hline
\end{tabular}


betydningen av hver enkelt faktor. Skjermede enheter begrenser stimuli, personalet er ofte spesielt utvalgt til å jobbe der og har spesialkompetanse innenfor feltet. I studier som sammenligner enerom og flersengsrom, inngår ofte andre aspekter, eksempelvis arkitektonisk utforming (9, 30-32).

Flere av tiltakene utnytter den kognitive svikten personer med demens har. Visuelle

ter. For mange, uforståelige stimuli (overstimulering) og/ eller få stimuli (understimulering) kan bidra til stress, angst, utfordrende atferd eller apati. Personalet kan eksempelvis lage områder $\mathrm{i}$ avdelingen som er beriket med positive stimuli og aktiviteter slik at beboerne trekkes mot disse stedene og tilrettelegge trygge områder inne $\mathrm{i}$ avdelingen eller i sykehjemmet hvor beboerne kan bevege seg

\section{Personalet kan lage områder i avdelingen som er beriket med positive stimuli.}

barrierer med striper på gulvet, speil og mørke tepper med spiralmønstre oppfattes som vellykkede hvis de hindrer beboere i å gå ut, men de kan også påføre beboerne emosjonelle belastninger som angst (33). De etiske sidene ved dette har vært problematisert (21). Jones og medarbeidere (33) påpeker at å bruke tegninger, kunstverk eller gamle gjenstander, male dører i samme farger som veggene og bruk av lys er nyere alternativer som er mindre emosjonelt belastende.

\section{Implikasjoner for pleiepersonalet}

Med utgangspunkt i de teoretiske perspektivene og kunnskap om hvordan ulike faktorer i omgivelsene påvirker personer med demens, kan pleiepersonalet bidra til å skape et godt og variert hverdagsliv. Ulike fysiske utforminger $\mathrm{i}$ avdelingen og sykehjemmet gir ulike forutsetninger for dette arbeidet.

De teoretiske perspektivene $(13,14,16,17)$ understreker betydningen av å skape omgivelser og en hverdag med tilpassede og varierte stimuli og aktivite- fritt. På denne måten kan sikkerheten og tryggheten ivaretas uten at fokuset er på barrierer som skal hindre at beboere går ut. Det er også viktig å ta hensyn til studier som rapporterer at beboere i små enheter ofte deltar mindre i organiserte aktiviteter. Dette innebærer at personalet i slike enheter har ansvar for å tilrettelegge for at beboerne kan få delta i aktiviteter som er tilpasset beboergruppen. Det kan skapes variasjon i hverdagen ved å legge aktivitetene til ulike steder i og utenfor avdelingen.

Personalet kan oppmuntre pårørende til å ta med personlige gjenstander til beboernes rom. Hjemliggjøringen av fellesarealene i sykehjemmet bør i den grad det er mulig ta utgangspunkt i diskusjoner med pårørende og eventuelt beboere. En utfordring er at hjemliggjøring er et vagt begrep og hva som oppfattes som hjemlig varierer, blant annet med sosiale forskjeller.

\section{Implikasjoner for videre forskning}

Majoriteten av oversiktsarti- klene har fokus på atferd og funksjon, spesielt regulering av utfordrende atferd. Av oversiktsartiklene med høy kvalitet hadde åtte fokus på «atferdsproblematikk». Det er viktig å utvikle kunnskap om hvordan de fysiske omgivelsene påvirker beboernes hverdagsliv, funksjon, trivsel og velvære og hvordan bruk av ulike steder i og utenfor sykehjem kan gi positive opplevelser og fremme trivsel og velvære. Utvikling av metoder for å kartlegge subjektive, positive utfallsmål er også nødvendig. De teoretiske perspektivene har hovedsakelig vært brukt for å forklare utfordrende atferd. De kan, etter vår oppfatning, også benyttes som fortolkningsramme for faktorer som bidrar til et godt hverdagsliv, trivsel og velvære for personer med demens.

\section{KONKLUSJON}

Det vitenskapelige grunnlaget for faktorene som inkluderes i demensvennlig design er svakt. Feltet preges av uklar begrepsbruk. Hovedfokus i oversiktsartiklene er på tiltak for å håndtere utfordrende atferd. Færre studier fokuserer på faktorer i omgivelsene som kan fremme trivsel og velvære. Fremtidig forskning bør ha et slikt fokus. De teoretiske perspektivene har hovedsakelig vært brukt til å forklare utfordrende atferd, men kan også være retningsgivende for faktorer som kan bidra til et godt hverdagsliv, funksjon og trivsel.

Artikkelen er skrevet på oppdrag fra Undervisningssykehjemmet i Oslo, Abildsø bo- og rehabiliteringssenter. Litteraturstudien er en del av prosjektet om miljøtiltak som inngår i Helsedirektoratets "paraplyprosjekt» Demensfyrtårn. 


\section{REFERANSER}

1. Werezak LJ, Morgan DG, Werezak LJ, Morgan DG. Creating a therapeutic psychosocial environment in dementia care. A preliminary framework. Journal of Gerontological Nursing 2003;29:1825.

2. Parker C, Barnes S, McKee K, Morgan K, Torrington J, Tregenza P. Quality of life and building design in residential and nursing homes for older people. Ageing \& Society 2004;24: 941-62.

3. Wogn-Henriksen K. Det må da gå an å ha det godt selv om man er glemsk! Miljøbehandling i demensomsorgen. I: Eidem Krüger RM. (red). Det går an! Muligheter i miljøterapi. Forlaget Aldring og helse, Sem. 2007: pp 18-35.

4. Day K, Calkins M. Design and dementia. I: Bechtel R, Churchman A (red). Handbook of Environmental Psychology. John Wiley and Sons, New York. 2002: pp 374-93.

5. Jamtvedt G, Dahm KT, Christie A, Moe RH, Haavardsholm E, Holm I, et al. Physical therapy interventions for patients with osteoarthritis of the knee: an overview of systematic reviews. Physical Therapy 2008;88:123-36.

6. Edgerton EA, Richie L. Improving physical environments for dementia care: making minimal changes for maximum effect. Annals of Long Term Care 2010;18:43-5.

7. Nasjonalt kunnskapssenter for helsetjenesten. Slik oppsummerer vi forskning. Håndbok for Nasjonalt kunnskapssenter for helsetjenesten. Nasjonalt kunnskapssenter for helsetjenesten, Oslo. 2009.

8. Landmark B, Kirkehei I, Brurberg KG, Reinar LM. Botilbud til mennesker med demens. Kunnskapssenteret, Oslo. 2009

9. Day K, Carreon D, Stump C. The therapeutic design of environments for people with dementia: a review of the empirical research. Gerontologist 2000;40:397-421

10. Calkins MP. Evidence-based long term care design. NeuroRehabilitation 2009;25: 145-54

11. Calkins MP. Special care units and the environment: advances of the past decade. Alzheimerss Care Quarterly 2001:2:41-8

12. Williams-Burgess C, Ugarriza D, Gabbai M. Agitation in older persons with dementia: a research synthesis. The Online Journal of Knowledge Synt- hesis for Nursing 1996:3:97-107.

13. Lawton MP, Nahemow L. Ecology and the aging process. I: Eisdorfer C, Lawton MP, (red). The psychology of adult development and aging. Washington D.C.: American Psychological Association, 1973:619-74.

14. Hall GR, Buckwalter KC. Progressively lowered stress threshold: a conceptual model for care of adults with Alzheimer s disease. Archives of Psychiatric Nursing 1987;1:399-406.

15. Corcoran M, Gitlin LN. Environmental influences on behavior of the elderly with dementia: principles for intervention in the home. Physical \& Occupational Therapy in Geriatrics 1991:9: 5-22. 16. Gitlin LN, Liebman J, Winter L. Are environmental interventions effective in the management of Alzheimerss disease and related disorders? A synthesis of the evidence. Alzheimer>s Care Quarterly 2003;4:85-107.

17. Cohen-Mansfield J. Nonpharmacologic interventions for inappropriate behaviors in dementia: a review, summary, and critique. American Journal of Geriatric Psychiatry 2001;9: 361-81. 18. Livingston $G$, Johnston $K$, Katona C, Paton J, Lyketsos CG, et al. Systematic review of psychological approaches to the management of neuropsychiatric symptoms of dementia. American Journal of Psychiatry 2005;162:1996-2021.

19. Siders C, Nelson A, Brown LM, Joseph I, Algase D, Beattie E, et al. Evidence for implementing nonpharmacological interventions for wandering Rehabilitation Nursing 2004:29:195206.

20. Doody RS, Stevens JC, Beck C Dubinsky RM, Kaye JA, Gwyther L, et al. Practice parameter: management of dementia (an evidence-based review). Neurology 2001; 56: 1154-66.

21. Price JD, Hermans DG, Grimley Evans J. Subjective barriers to prevent wandering of cognitively impaired people. Cochrane Database of Systematic Reviews 2000: CD001932.

22. Opie J, Rosewarne R, O Connor DW. The efficacy of psychosocial approaches to behaviour disorders in dementia: a systematic literature review. Australian \& New Zealand Journal of Psychiatry 1999:33: 789-99.

23. Lai CK, Yeung JH, Mok V, Chi I, Lai CK, Yeung JH, et al. Special care units for dementia individuals with behavioural problems. Cochrane Database of
Systematic Reviews. 2009: CD006470. 24. Zuidema S, Koopmans R, Verhey F. Prevalence and predictors of neuropsychiatric symptoms in cognitively impaired nursing home patients. Journal of Geriatric Psychiatry \& Neurology 2007:20:41-9

25. Robinson L, Hutchings D, Corner L, Beyer F, Dickinson $H$, Vanoli $A$, et al. A systematic literature review of the effectiveness of non-pharmacological interventions to prevent wandering in dementia and evaluation of the ethical implications and acceptability of their use: Health Technology Assessment 2006;10

26. Kong EH, Evans LK, Guevara JP. Nonpharmacological intervention for agitation in dementia: a systematic review and meta-analysis. Aging \& Mental Health 2009:13:512-20.

27. Kverno KS, Black BS, Nolan MT, Rabins PV. Research on treating neuropsychiatric symptoms of advanced dementia with non-pharmacological strategies, 1998-2008: A systematic literature review. International Psychogeriatrics 2009;21:825-43

28. Roberts J, Browne G, Gafni A, Varieur M, Loney P, De Ruijter M. Specialized continuing care models for persons with dementia: A systematic review of the research literature. Canadian Journal on Aging 2000;19:106-26.

29. Verbeek H, van Rossum E, Zwakhalen SM, Kempen GI, Hamers JP. Small, homelike care environments for older people with dementia: a literature review. International Psychogeriatrics 2009;21:252-64.

30. Annerstedt L. An attempt to determine the impact of group living care in comparison to traditional long-term care on demented elderly patients. Aging-Clinical \& Experimental Research 1994;6:372-80.

31. Annerstedt L. Group-living care: an alternative for the demented elderly. Dementia \& Geriatric Cognitive Disorders 1997:8:136-42

32. Skea D, Lindesay J. An evaluation of two models of long-term residential care for elderly people with dementia. International Journal of Geriatric Psychiatry 1996;11:233-41.

33. Jones GMM, van der Eerden WJ. Designing care environments for persons with Alzheimerss disease: visuoperceptual considerations. Reviews in Clinical Gerontology 2008;18:13-37. 